\title{
IMPACT OF FOOD PRICE INCREASE ON POOR HOUSEHOLDS IN SRI LANKA
}

\author{
DN Koralagama* and AL Sandika \\ Department of Agricultural Economics, Faculty of Agriculture, University of Ruhuna, Mapalana, Kam- \\ brupitiya, Sri Lanka
}

Accepted: $3^{\text {rd }}$ February 2012

\begin{abstract}
Food price inflation was one of the major crises mooted in recent past. Marginalized poor people were hammered largely in developing countries including Sri Lanka. The awareness and preparedness for food crisis can reduce the impact as well as the social conflicts up to a certain extent. Hence, this study was designed to find out the awareness and impact of food price inflation among poor householders in rural Sri Lanka. A survey questionnaire was employed over 100 Samurdhi beneficiaries from Gampaha and Matara Districts. Data were analyzed using SPSS package. The results showed a positive relationship between education and level of awareness on food crisis $(r=0.325, P=0.001)$. The majority of the sample was $(77 \%)$ aware about the world food crisis and $88 \%$ of them has experienced it due to high prices of food commodities. The reasons they have put forwarded were climate change and lack of land for agriculture. There was a significant impact on spending on foods $(p=0.000)$ where the food expenses have increased after 2008 drastically. People have tried out to substitute wheat flour based products with rice based products showing a significant association between wheat and rice consumption $\left(\chi^{2}=13.05, P=0.000\right)$. The rural poor in Sri Lanka were aware about world food crisis with some valid justifications. Hence, they tend to go for substitutes in order to smooth the negative impact of high food prices. Hence, the government can formulate policies toward import substitutes especially on food items as the perception of rural poor is favourable to lessen the threat of food crisis in future.
\end{abstract}

Key words: Awareness, Food crisis, Samurdhi beneficiaries

\section{INTRODUCTION}

Escalating food prices lead to numerous problems in the economy. It is a threat for the economic stability within the country so as in the world (World Bank 2011). Increasing food prices lead to reduce the household welfare where the total food consumption takes a larger share from the total expenditure, especially on poor households (World Bank 2008). The global food prices are sky rocketing from 2006 to 2011. The World Bank food price index rose to its highest in 2008 affirming a "food price crisis" in year 2008 (Ivanic et al. 2011). As per Demeke et al. (2008) the world food prices has increased by $40 \%$ in 2007 demarcating the highest food prices within recent past. All these statistics describe about some sort of a food price increase, which has appeared as unbearable to the economies of the world. On the other hand, the high prices of foods create a fatal threat for poor nations in the world. Because, food price rises lead macro level vulnerability especially for low income countries with a high share of food imports and limited monetary earning (World Bank 2011). In fact, increasing food prices would cause on poverty,

*Corresponding author: dilanthi@agecon.ruh.ac.lk starvation, malnutrition, and many other issues by creating a crisis in the world especially in developing countries like Sri Lanka (Ivanic et al. 2011).

Being the staple food of the country, rice price has increased by $30 \%$ in 2008 (Central Bank 2010). Also, the wheat price has increased by $31 \%$ affecting all the bakery products as well as cottage industries in the rural community in Sri Lanka (World Bank 2011). According to the FAO (2009) the food price inflation is about $31 \%$ in Sri Lanka in 2008. Also, the rice imports increased from 52,000t in year 2009 to $126,000 t$ in year 2010 and sugar production decrease by $2.6 \%$ in 2010 (Census and Statistics 2010). In 2008, the rice price inflation in Sri Lanka was only second to Bangladesh from the region even though the price level was fairly lower than the global rice price (Regional food prices, World bank). These are certain signs of a food crisis that can be experienced in Sri Lankan economy creating the worst food price inflation (Bandara and Selvanathan, 2008) as well as the highest food price inflation rate (FAO 2009) in South Asia. 


\section{Main reasons for food prices increase}

Much lands and resources are needed to feed the ever growing population. Same time, people demand land for housing, construction, and infrastructure. Therefore, the arable lands shrink day by day. This would lead to reduce the food production unless we do not increase the productivity of agricultural lands. Also, the unpredictable weather and the climate change disturb crop production further. Moreover, the increase world food prices and the oil prices lower the amount of imports. On the other hand, the low production would reduce the volume of exports while letting down the bargaining power of the country. All these forces lead to create a shortage of food supply within the country. At the worst case, this appears as a food crisis (Eric 2008).

\section{The threat of food crisis}

The volatile food prices followed by the food crisis make people more vulnerable and risk on hunger. The world malnutrition people have increased to one billion as an impact of food crisis in mid 2008 (Viatte et al. 2009). Ministry of Health and the department of Census and Statistics in Sri Lanka has mentioned in one of the reports that the soaring food prices result negative impacts on dilatory quality of the populace (Colombo Page, 2011). The recent records show that 44 million people in the world have been fallen below the 1.25 USD per day extreme poverty line just because of the food price increase in 2010 (Ivanic et al. 2011). It further elaborates that the poverty change in low income countries and middle income countries are $1.1 \%$ and $0.7 \%$ respectively. When this comes to Sri Lanka, the figure goes up to $1.44 \%$ which is above the world average even for low income countries.

In a situation of food crisis the most people cannot access to foods due to high prices. High food prices would marginalize the poor rural communities where a major portion of their income is spending for foods. If the food prices are increasing, the available income to meet other basic needs like, clothes, sanitary facilities, safety, and so on will shrink. This would keep them away from a decent life but pushing below the poverty line. The most vulnerable group for the food crisis is poor household. They have to meet all the expenses including food from the limited and uncertain daily income. Also, they pay a huge proportion for foods from their income. In that sense, the soaring food prices would further increase the proportion of income for food forcing to reduce the other expenses on education, clothes, health and so on.

Blas and Minder (2008), stated that the food crisis is the most serious problem for Asians than the global economic crisis. All these literature explains the negative consequences of the food crisis which would slow down the economy of a country. In fact, it is worthwhile to pay an attention to detect the impact of food crisis on Sri Lankan economy which would be much helpful to be aware on the severity of it. Then only, we can build and corporate toward the national strategies which are implemented by the government as one nation.

Obviously, this would drag them away from a decent life. Hence, it is paramount to investigate about the level of impact of food price increment on poor households. Also, the awareness and the precautionary measures that have been taken by the poor communities in Sri Lanka would be essential to overcome from this calamity. In fact, this study attempts to study the community awareness regarding food crisis and the impact of food price increment to their consumption pattern.

\section{METHODOLOGY}

The study was mainly designed to investigate the level of awareness and the impact of food crisis on poor households in Sri Lanka. In fact, before and after 2008 was considered to assess the impact of food price increase on the level of consumption of the poor (a high price inflation could be seen in year 2008 (worldbank.org). Since, it is difficult to cover the changes of consumption of all the food commodities only two basic commodities; rice and bakery products (wheat) were taken into consideration due to high price increases in rice and wheat where those are playing as close substitutes, too.

In order to achieve the objectives, both primary and secondary data were collected. The primary data were collected through a pretested questionnaire survey. Here, the target population was Samurdhi beneficiaries (those 
recognized by the government as marginalized poor households who cannot even fulfill their basic needs). In fact, a sample of 100 households from Gampaha and Matara districts were selected. Gampaha district comprised the highest number of Samurdhi recipients and Matara was the second (Samurdhi Authority 2011). Simple random sampling technique was employed using a list of Samurdhi beneficiaries over five Grama Niladhari divisions from each district. Variables such as share of spending, education, occupation, awareness on food crisis, and its impact on expenses on food, education, clothes, and entertainment were taken as the variables to achieve the objectives. Other than the field survey, informal discussions with Grama Niladhari were conducted. The secondary data were gathered through reports, journals etc. The data were analyzed using SPSS statistical package to interpret the gathered information. There, Pearson correlation, Kruskal Wallis test, Chi square, and t-test were employed to analyze the data empirically.

\section{RESULTS AND DISCUSSION}

A majority interviewed was farmers (42\%) and self employment in cashew processing and carpentry was the second main occupation category $(21 \%)$ (Fig. 1). Further, $77 \%$ of the

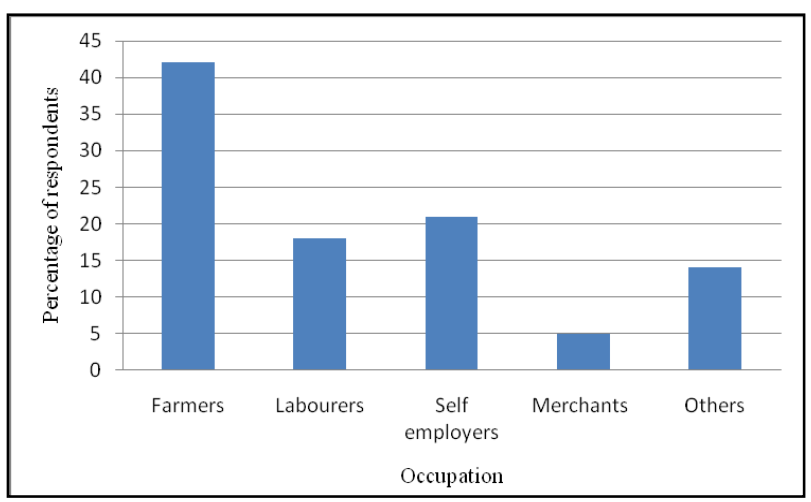

Figure 1: Occupation of the respondents

householders were aware about the world food crisis. Of that $88 \%$ have experienced the food crisis as the increase of food prices (Fig 2). But, $12 \%$ have felt it due to the shortage of food.

The respondents were not well educated. They were marginalized people earning only to meet the day today consumption expenses. But,

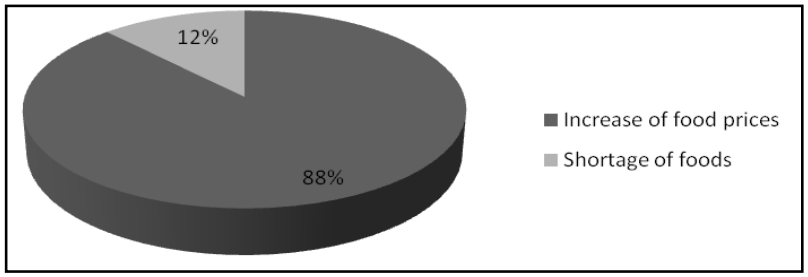

Figure 2: Experience of food crisis by the poor householders

there was a significant relationship between their level of education and the awareness on world food crisis $(\mathrm{r}=0.35, \mathrm{P}=0.001)$ at 0.01 confidence level. In fact, the awareness on food crisis is going in hand with the level of education.

We observed that climate change and lack of land for agriculture as the main reasons for food crisis from the point of view of poor households. They have perceived bad politics and oil prices increase as the third and forth root cause for the problem. But, the mean separation shows that there were not much difference between the responses of first two and the third and the fourth (Table 1). However, this explains that the poor householders are at least knowledgeable to give a logical reason for the food crisis. These findings were a line with the interpretation of Bandara and Selvanathan (2008) and Eric (2008).

Table 1: Reasons for food crisis - from poor householders' view point

\begin{tabular}{ll}
\hline Factor & Mean Rank \\
\hline Climate change & $78.17^{\mathrm{a}}$ \\
Lack of land for agriculture & $79.08^{\mathrm{a}}$ \\
Politics & $164.04^{\mathrm{b}}$ \\
Oil price increase & $169.70^{\mathrm{b}}$ \\
Malpractices of traders & $202.72^{\mathrm{c}}$ \\
World destruction & $232.69^{\mathrm{d}}$
\end{tabular}

* No significant difference between values of same letters at 0.05

The analysis of the spending on certain consumption items (Table 2) indicated a significant difference at 0.01 on food expenses before and after 2008. But, the expenditure on clothes, education, and entertainment do not show any significant difference even though the food prices increased. In general, the mean difference depicts a positive value revealing an increment of expenses up to certain extent. Here, the poor marginalized people whose income is only sufficient to fulfill their basic needs. Hence, it is obvious that there is no way 
Table 2: Impact of food crisis for expenditure pattern on poor householders

\begin{tabular}{|c|c|c|c|c|}
\hline Item & Before 2008 & After 2008 & $\begin{array}{l}\text { Mean dif- } \\
\text { ference }\end{array}$ & $\begin{array}{l}\text { Signifi- } \\
\text { cant } \\
\text { level }\end{array}$ \\
\hline Food & $\begin{array}{l}\text { mean }=50.4 \\
\mathrm{SD}=13.9\end{array}$ & $\begin{array}{l}\text { mean }=59.4 \\
\mathrm{SD}=14.4\end{array}$ & 9.1 & $0.000^{*}$ \\
\hline Clothes & $\begin{array}{l}\text { mean }=9.5 \\
\mathrm{SD}=7.8\end{array}$ & $\begin{array}{l}\text { mean }=12.1 \\
\mathrm{SD}=10.9\end{array}$ & 2.7 & 0.05 \\
\hline & $\begin{array}{l}\text { mean }=16.7 \\
S D=9.6\end{array}$ & $\begin{array}{l}\text { mean }=20.3 \\
\mathrm{SD}=12.5\end{array}$ & 4.6 & 0.026 \\
\hline $\begin{array}{l}\text { Entertain- } \\
\text { ment }\end{array}$ & $\begin{array}{l}\text { mean }=6.1 \\
\mathrm{SD}=4.3\end{array}$ & $\begin{array}{l}\text { mean }=6.1 \\
\mathrm{SD}=5.6\end{array}$ & $3.147 \mathrm{E}-02$ & 0.966 \\
\hline
\end{tabular}

* Significant at 0.01

to reduce their level of expenses on items such as education, clothes, and entertainment. But, inflation moves prices of all the commodities resulting more spending on each item. In essence, it was possible to elicit that there was a significant difference on food expenditure before and after 2008 which was not noticeable in other consumption items of poor householders. Moreover, they have changed their eating habit. A remarkable reduction in wheat consumption (54\%) was observed. They were used to consume more rice than bakery products made of wheat flour $\left(\chi^{2}=13.05\right.$, $\mathrm{P}=0.000)$ significant at 0.05 confidence level. Being most of the respondents are paddy farmers $(42 \%)$ rice is available at a cost. The wheat price inflation was about $130 \%$ (Eric 2008). Therefore, they have substituted wheat products with rice based food items.

\section{CONCLUSION}

The lowest income earners in rural community are less educated, however, they have a sound awareness on world food crisis. They realized food crisis is due to food price hike rather than a shortage of foods. The poor marginalized households in rural areas have perceived the food crisis as a consequence of climate change and lack of arable lands. But, some have stated it was due to bad politics and malpractices. However, the reasons they were putting forward are logical. It depicts that the rural poor are aware about the present situation and understand about the world scenario.

The food price inflation has stressed on the food expenses but not for expenditure on clothes, education, and entertainment. In fact, they have changed their eating habit. The most expensive wheat flour based bakery products have been substituted with rice based products as majority were paddy farmers in the sample. It was observed that the poor households were not able to overcome the food crisis in spite of their awareness of the issue. The higher food prices lead them search for cheaper substitutes. This gives an opportunity to the government to promote local cheap to grow food crops as substitutes and introduce new policies to combat with the crisis in future.

\section{REFERENCES}

Bandara SJ and Selvanathan S 2008 Impact of rising global food prices and policy responses in South Asia, Griffith University, Queensland, Australia. URL: http://www.sueztosuva.org.au/ south asia/ehs_conference/papers/Bandara.pdf

Blas J and Minder R 2008 Rice traders hit by panic as prices surge, Financial Times, April 17, 2008.

Central Bank of Sri Lanka, Annual report -2008 2010 Central Bank of Sri Lanka, Colombo.

Colombo Page, Malnutrition before food crisis in Sri Lanka http://www.colombopage.com/ archive 08/August7112523KA.html .

Demeke $\bar{M}$, Pangrazio G and Maetz M 2008 Country responses to the good security crisis Nature and preliminary implications of the policies pursued. Food and Agriculture organization, Rome.

Department of Census and Statistics 2010 Colombo, Sri Lanka

Eric H 2008 Ending injustices that cause hunger and environmental destruction, Food First: Policy brief No 16, Institute for food and development policy, California.

FAO 2009 Responding to the food crisis: Synthesis of medium term measures proposed in inter agency assessment, Food and Agriculture organization, Rome.

Ivanic M, Martin W and Zaman H 2011 Estimating the short run poverty impacts of the $2010-2011$ surge in food prices. Policy research working paper 5633, World Bank.

Regional Food Prices: http://siteresources.world bank.org/SOUTHASIAEXT/Resources/2235461269620455636/6907265-1287693474030/Ch1 RegionalFoodPrices.pdf

Samurdhi Authority : www.samurdhi.gov.lk.

Viatte G, De Graff J, Demeke M, Takahatak T and De Arce MR 2009 Food and Agricultural Organization, Rome. 
World Bank 2008 Addressing the food crisis: The need for rapid and coordinated action, Background Paper prepared for the Group Eight Meeting of Finance Ministers, 13-14 June, Osaka.
World Bank 2011 Food price Watch. The World Bank: http:// siteresources. worldbank. org/ SOUTHASIAEXT/ Resources/ 2235461269620455636/6907265-1287693474030/ LKA_Regional_Food_Prices.pdf 